\title{
SEJARAH PEMIKIRAN PANDANG KE TIMUR PADA ERA TUN HUSSEIN ONN
}

\author{
Uqbah Muhammad Iqbal \\ Nordin Hussin
}

\begin{abstract}
This article analyzes the history of the 'Look-To-The-East' ideas in Malaysia in the period of Tun Hussein Onn's administration. Over a decade after 1945, there were no official bilateral relations between Japan and the Malaya as Malaya was under British occupation again. Official bilateral relation between the Federation of Malaya and Japan only started when Kishi Nobosuke visited the Federation on 24 and 25 November 1957. Economic relations improved during the administration of Tun Abdul Razak when Japan's Official Development Assistance (ODA) financed the bulk of the Malaysia's development projects. Malaysia and Japan's economic relations strengthened during the administration of Tun Hussein Onn through the establishment of the MalaysiaJapan Economic Association (MAJECA) and Japan-Malaysia Economic Association (JAMECA). The Look-To-The-East ideas seemed unlikely to fade after the Second World War until the period of Tun Hussein Onn administration, a long period of 34 years. When Tun Dr. Mahathir Mohamad continued the Look-To-The-East ideas that led to the formation of the Look-To-The-East Policy, Japanese investment in the country grew and Japan emerged as Malaysia's major trading partner.
\end{abstract}

\section{Pengenalan}

Tun Hussein Onn sebagai Perdana Menteri tetap mempunyai dampaknya yang tersendiri, terutama sekali apabila beliau meneruskan cita-cita Zone of Peace, Freedom and Neutrality (ZOPFAN) dan matlamat 
Dasar Ekonomi Baru (DEB) menerusi Rancangan Malaysia Ketiga dan Keempat. Karier politik beliau dibayangi ketokohan bapanya sebagai pengasas kepada pertubuhan UMNO. Sebagaimana dalam era Tun Abdul Razak, Tun Hussein Onn turut menggangkat Persatuan Negaranegara Asia Tenggara (ASEAN) sebagai wahana yang paling penting bagi mengukuhkan kerjasama serantau. Bagi menjamin pengekalan kemerdekaan negara dan menjaga integriti wilayah, beliau berpegang teguh kepada prinsip berkecuali. Malaysia turut meneruskan hubungan dengan beberapa pertubuhan seperti ASEAN, Komanwel, Pertubuhan Bangsa-Bangsa Bersatu (PBB), Pergerakan Negara-negara Berkecuali (NAM) dan Pertubuhan Persidangan Islam (OIC). Dari aspek ekonomi, orientasi negara juga ke arah mendekatkan diri dengan Negara-negara Dunia Ketiga atau Negara Selatan-selatan.

Jika dilihat menerusi kajian-kajian lepas, didapati tiada sebarang kajian ilmiah, tesis atau karya umum yang pernah menyentuh mengenai pemikiran Pandang Ke Timur semasa era pentadbiran Tun Hussein Onn. Kajian-kajian sebelum ini lebih banyak menyentuh mengenai dekolonisasi wilayah British secara umumnya dan sejarah Tanah Melayu selepas Perang Dunia Kedua serta menrungkai kepentingan ekonomi Tanah Melayu kepada British. Malah turut menjadi fokus utama dalam kajian lepas seperti konflik antara Jepun dan negara-negara Barat dari segi politik, sosial dan ekonomi di peringkat antarabangsa serta hubung kait antara Asia Tenggara dengan pembinaan semula ekonomi Britain dan Jepun.

\section{Kepentingan Jepun Dalam Ekonomi Malaysia}

Seperti pentadbiran Tunku Abdul Rahman dan Tun Abdul Razak, pentadbiran Tun Hussein Onn juga memperhebatkan usaha untuk menarik lebih banyak pelaburan asing, khususnya dari Jepun. ${ }^{1}$ Bermula pada 17 Januari 1977, The Associated Malay Chambers of Commerce (AMCC) menjemput usahawan Jepun untuk mendirikan usahasama di Malaysia bagi membangunkan industri petroleum tempatan. Naib Presiden AMCC, Raja Khalid bin Raja Harun menjelaskan terdapat beberapa buah syarikat Malaysia termasuk pemilikan penuh Bumiputera telah ditubuhkan dengan tujuan utama untuk menyediakan peralatan dan perkhidmatan kepada syarikat-syarikat minyak. Rakyat Malaysia terutamanya Bumiputera kekurangan kepakaran dan pengetahuan teknikal dalam industri petroleum. Pelabur asing yang mahir dalam dua perkara ini dialu-alukan mengadakan usahasama dengan kerajaan. ${ }^{2}$ Pada 24 Februari 1977, Ketua Unit Promosi Pelaburan Lembaga Kemajuan Perusahaan Persekutuan (FIDA), J. Jegathesan menyatakan Jepun merupakan antara pelabur asing yang terkemuka 
di Malaysia dan kerajaan mengharapkan Jepun akan terus memainkan peranan aktif dalam Rancangan Malaysia Ketiga. Kerajaan juga berharap pelabur-pelabur Jepun akan terus datang dan terlibat dalam industriindustri usahasama. ${ }^{3}$

Dalam lawatan Tun Hussein Onn ke Jepun pada 18 hingga 23 September 1977, perbincangan utama ditumpukan kepada masalah antarabangsa dan soal hubungan dua hala antara Malaysia dan Jepun. Hubungan Malaysia dan Jepun sangat erat, misalnya Jepun terlibat secara langsung dalam memberi bantuan kewangan kepada Malaysia dalam perlaksanaan rancangan DEB. Jepun juga telah memberi pinjaman dalam perlaksanaan Rancangan Malaysia Pertama, Kedua dan Ketiga. Hasil perbincangan antara Tun Hussein Onn dengan Perdana Menteri Jepun, kerajaan Jepun bersedia menambahkan bantuan kewangan kepada Malaysia sebanyak RM 21 billion khusus bagi membantu perlaksanaan Rancangan Malaysia Ketiga. Pada 16 Januari 1978, satu upacara menandatangani pertukaran nota-nota mengenai Kredit Yen keempat telah diadakan di Bilik Gerakan Negara, Jabatan Perdana Menteri. ${ }^{4}$ Selain daripada bantuan kewangan, kerajaan Jepun juga bersedia memberi bantuan dari segi teknikal. ${ }^{5}$

Tun Hussein Onn berpandangan bahawa hubungan ASEAN dengan Jepun adalah bersifat bergantungan dalam pelbagai perkara. Kerjasama menjadi lebih berkesan dan bermakna sekiranya melibatkan minat daripada kedua-dua perkara. Lawatan oleh Perdana Menteri Jepun, Takeo Fukuda ke semua negara ASEAN mengukuhkan lagi pandangan ini. Beliau menyatakan bahawa lawatan Takeo Fukuda ke Kuala Lumpur pada 9 Ogos $1977^{6}$ telah mengubah persekitaran ekonomi, daripada kebimbangan tahap hubungan masa depan keduadua negara kepada harapan dan keyakinan. ${ }^{7}$ Beliau juga berharap pelaburan Jepun di Malaysia akan dapat membantu pembangunan ekonomi dan sosial negara. ${ }^{8}$ Ini kerana kerajaan tidak begitu berminat dengan hubungan kebudayaan yang lebih rapat antara kedua-dua negara, melainkan bantuan kewangan dan pelaburan serta akses yang lebih baik kepada pasaran Jepun. Lawatan Fukuda ini juga mendapat sambutan baik daripada rakyat Malaysia berbanding lawatan Tanaka pada tahun 1974 dan ini menunjukkan penerimaan imej Jepun yang semakin baik. ${ }^{9}$ Lawatan Fukuda ini telah dibalas dengan kunjungan Tun Hussein Onn ke Jepun pada 18 September $1977 .^{10}$

Kepentingan Jepun dalam pembangunan ekonomi negara boleh dilihat apabila Malaysia mula mempertimbangkan untuk membina armada kapal negara dan Jepun dijadikan sebagai negara untuk mempelajari ilmu perkapalan. ${ }^{11}$ Kepentingan pelaburan asing terutama Jepun boleh dilihat dalam sasaran pelaburan yang ditetapkan di bawah Rancangan Malaysia Ketiga (1976-1980) untuk pencapaian oleh 
sektor pembuatan. Timbalan Perdana Menteri merangkap Menteri Perdagangan dan Perindustrian ketika itu, Dato' Seri Dr. Mahathir Mohamad menyatakan bahawa para pelabur Cina di Malaysia gagal melahirkan industri pengeluaran berasaskan eksport dengan kukuh, ${ }^{12}$ ini menyebabkan Malaysia memerlukan pasaran teknologi luar untuk membantunya serta memperbaiki lagi iklim pelaburan luar negara di Malaysia. ${ }^{13}$

Pada 15 November 1977, Tun Hussein Onn memberikan jaminan mutlak kepada golongan perniagaan Jepun bahawa kerajaan akan melakukan segala yang mungkin untuk menggalakkan peningkatan penyertaan sektor swasta tempatan ke dalam pembangunan ekonomi negara demi menarik masuk lebih banyak pelaburan asing. ${ }^{14}$ Beliau berharap agar Jepun akan memainkan peranan dalam membentuk kerjasama bukan sahaja antara sektor swasta Malaysia dan Jepun, tetapi juga antara sektor swasta Jepun dengan kerajaan Malaysia. Walaupun penyertaan Jepun dalam pembangunan ekonomi dan perindustrian Malaysia agak besar, namun kerajaan memerlukan dan menggalakkan penyertaan yang lebih banyak kerana pembangunan ekonomi dan sosial Malaysia walaupun nampak memberansangkan tetapi masih tidak mencukupi. Hal ini kerana masih terdapat banyak kawasankawasan mundur di negara ini. Di samping itu Tun Hussein Onn juga memberikan penghargaan kepada sektor swasta Jepun yang dianggap antara pengurusan terbaik di dunia. ${ }^{15}$

Pemikiran Pandang Ke Timur dalam pentadbiran Tun Hussein Onn mencapai kemuncaknya pada tahun 1977 melalui penubuhan MAJECA di Malaysia ${ }^{16}$ dan JAMECA di Jepun. Dua kumpulan pelobi Jepun, MAJECA dan JAMECA ${ }^{17}$ telah ditubuhkan dengan matlamat untuk menggalakkan hubungan ekonomi yang lebih erat bagi kepentingan nasional kedua-dua pihak dalam ekonomi global yang sangat kompetitif. Kesinambungan pemikiran Pandang Ke Timur oleh kerajaan Malaysia boleh dikaitkan dengan peranan individu ${ }^{18}$ dan kumpulan tertentu di peringkat rasmi dan tidak rasmi. ${ }^{19}$ Mereka ini berjaya menarik perhatian kepimpinan kerajaan dan seterusnya mempengaruhi orientasi dasar kerajaan.

Menjelang pertengahan tahun 1970-an, muncul golongan kelas perniagaan Melayu baru. ${ }^{20}$ Mereka ini mendapat sokongan kuat daripada pihak kerajaan dan mula menjalinkan hubungan rapat dengan ahli perniagaan Jepun. Pihak kapitalis bukan Melayu, khususnya individu-individu yang telah menjalin hubungan yang lebih panjang dengan Jepun, terlibat juga dalam usaha kerajaan untuk mempromosikan usahasama antara Malaysia dan Jepun. Perikatan antara golongan kelas perniagaan Melayu baru, rakan peniaga Cina dan pelabur Jepun melalui MAJECA dan JAMECA ${ }^{21}$ telah memainkan 
peranan penting dalam menggalakkan perkembangan pemikiran Pandang Ke Timur sehingga tercetusnya Dasar Pandang Ke Timur kemudiannya. Pada 16 Februari 1979, Tun Hussein Onn bagi pihak Duli Yang Maha Mulia Seri Paduka Baginda Yang di-Pertuan Agong telah mengurniakan darjah utama Panglima Mangku Negara (PMN) yang membawa gelaran Tan Sri kepada Konosuke Matsushita, pengasas dan penasihat eksekutif Matsushita Electric Industrial Company Limited di pejabatanya. Matsushita telah dikurniakan darjah tersebut kerana menghargai kejayaan cemerlang beliau dalam kemajuan dan perkembangan perdagangan serta perhubungan pelaburan antara Malaysia dan Jepun. ${ }^{22}$

Di bawah Doktrin Fukuda pada tahun 1977, Jepun menekankan komitmennya untuk mencapai keamanan dan tidak sesekali akan memunculkan diri sebagai kuasa ketenteraan semula. Doktrin Fukuda memberikan imej baru kepada Jepun, di mana Takeo Fukuda pada masa tersebut secara terbuka memohon maaf atas kekejaman yang dilakukan tentera Jepun sewaktu Perang Dunia Kedua. Seterusnya Doktrin Fukuda telah menjadi pemangkin kepada usaha membina hubungan baik secara diplomasi antara Jepun dan negara serantau. ${ }^{23}$ Penekanan ASEAN sebagai teras polisi Jepun di Asia Tenggara menjadikan Doktrin Fukuda sebagai titik peralihan hubungan Jepun-ASEAN. Doktrin Fukuda juga menandakan pengesahan rasmi Jepun terhadap ASEAN sebagai satu organisasi serantau dan aktor utama di rantau Asia Tenggara. Hubungan khas Jepun-ASEAN dianggap sebagai faktor penentu kepada kestabilan dan kemakmuran serantau. ${ }^{24}$

Di bawah Doktrin Fukuda, Jepun berikrar ke arah kerjasama ekonomi dan perhubungan "dari hati ke hati” dengan negara-negara ASEAN. Faktor-faktor yang terlibat dalam perubahan sikap Jepun ini termasuk keinginan Presiden Carter untuk melihat Jepun lebih melibatkan diri dengan ASEAN. Semakin kuatnya perpaduan keduadua pihak akan melahirkan kuasa perundingan yang lebih teguh dalam kalangan negara-negara ASEAN. Pengisytiharaan Doktrin Fukuda bukan sahaja memenuhi keperluan politik Asia Tenggara yang sedang berubah tetapi juga memberi sumbangan kestabilan dan meningkatkan pengaliran pelaburan asing di ASEAN. Doktrin ini juga dilancarkan ketika ASEAN memerlukan dana bagi projek bersamanya yang pertama. ${ }^{25}$

Pada tahun 1978, Presiden Topla Limited, ${ }^{26}$ Y. Nakagawa menyatakan tempoh 10 tahun lepas menunjukkan persekitaran pelaburan di Malaysia adalah baik dan salah satu yang paling menarik di rantau ASEAN. Dengan kestabilan politik dan ekonominya, Malaysia boleh mengharapkan lebih banyak pelaburan Jepun. Pembangunan Jepun yang pesat pula menyebabkan industrinya dilanda peningkatan 
kos dan persaingan yang sangat kuat telah menyebabkan aktiviti ekport sukar dilakukan dari Jepun. Oleh itu syarikat-syarikat Jepun sangat berminat untuk melabur di negara-negara lain khususnya di rantau ASEAN. Pelaburan syarikat-syarikat Jepun di Malaysia akan menjadi lebih murah dan mudah bagi tujuan mengekport kembali produk siap ke Jepun. ${ }^{27}$ Tahun yang sama juga menyaksikan Timbalan Ketua Eksekutif Kumpulan Sime Darby Holdings, Tunku Dato' Ahmad bin Tunku Yahaya menggesa Jepun membuka pintu kepada kemasukan barangan ASEAN bagi mendapat faedah daripada segala kemungkinan pelaburan yang menarik. Para pelabur Jepun juga tidak perlu merasa bimbang akan pembiayaan projek-projek di Malaysia kerana kerajaan sudah bersedia untuk menarik kemasukan pelaburan asing yang baik dan berdaya maju. Masalah yang sering dihadapi oleh Malaysia dan juga negara-negara ASEAN yang lain ialah kekurangan teknologi dan di sinilah Jepun dapat memainkan peranannya. ${ }^{28}$

Pada 11 November 1978, Dato' Seri Dr. Mahathir Mohamad menggesa para pelabur tempatan untuk merebut peluang yang diberikan oleh kerajaan dengan mengadakan kerjasama dengan para pelabur Jepun dalam projek-projek usahasama. Ini terutamanya setelah beliau memainkan peranannya dalam meransang minat para pelabur Jepun untuk datang ke Malaysia. ${ }^{29}$ Pada 7 Oktober 1978, Menteri Industri Utama Malaysia, Paul Leong menggesa Jepun untuk meningkatkan usahasama perindustrian dengan rakan kongsi tempatan dan beliau menekankan usahasama dalam sektor berasaskan kayu dan kelapa sawit. ${ }^{30}$ Pada 3 Julai 1979, Timbalan Menteri Kewangan, Datin Paduka Rafidah Aziz menyatakan Malaysia mengalukan sebarang langkah dari Jepun untuk menubuhkan Perjanjian Jaminan Pelaburan selepas menjangkakan peningkatan dalam hubungan perdagangan dan pelaburan antara kedua negara. Perjanjian ini yang telah dilakukan bersama beberapa negara lain sejak tahun 1959 bagi menghilangkan sebarang keraguan daripada Jepun akan keselamatan pelaburan asing di Malaysia. Malah perjanjian ini juga akan membetulkan sebarang salah faham Jepun mengenai Dasar Ekonomi Baru dan kerajaan sentiasa memberikan jaminan tidak akan berlakunya pengambil alihan pelaburan asing di Malaysia. ${ }^{31}$

Menjelang tahun 1978 hubungan Malaysia-Jepun menjadi semakin penting dengan perkembangan yang berlaku di Indochina. Pencerobohan tentera Vietnam di Kemboja pada 25 Ogos 1978 hingga 7 Januari 1979 telah memberi kesan terhadap kestabilan dan keselamatan negara-negara ASEAN. ${ }^{32}$ Masalah yang berlaku di Kemboja memperatkan hubungan politik antara Malaysia dan Jepun. Persidangan dua hari menteri-menteri ekonomi ASEAN yang bermula di Tokyo pada 26 November 1979 telah melahirkan satu peryataan bersama bahawa 
para peserta bersetuju bahawa hubungan antara Jepun dan ASEAN akan terus berkembang dan meluaskan lagi kerjasama mereka demi keamanan dan kemakmuran di rantau Asia. Jepun juga digesa untuk mengkaji serta memperkemaskan program bantuan pembangunan bagi menyokong strategi baru pembangunan ASEAN dalam tahun 1980-an. ${ }^{33}$

Pada bulan Julai 1979, Pengerusi Lembaga Kemajuan Perindustrian Malaysia (MIDA), Dato' Jamil Jan memberi jaminan kepada Jepun bahawa mereka tidak akan menghadapi persaingan dari segi perindustrian dengan Malaysia di sebalik bantuan yang dihulurkan selama ini. Peluang untuk Malaysia menjadi Jepun yang kedua adalah sangat jauh, dan Jepun tidak seharusnya mempunyai kebimbangan itu. Malaysia bukanlah cuba mengambil pekerjaan daripada penduduk Jepun, tetapi untuk melengkapi ekonomi Jepun. Tenaga buruh Jepun yang mahal, canggih dan berkemahiran tinggi tidak seharusnya dibazirkan untuk menghasilkan produk-produk yang bernilai rendah. Mereka seharusnya digunakan untuk produk-produk yang berteknologi tinggi dan mempunyai nilai tambah yang tinggi. Malaysia pula boleh menghasilkan produk-produk kurang canggih dan intensif buruh yang masih diperlukan oleh dunia. Jikapun Malaysia berjaya meningkatkan keupayaan perindustriannya, kedudukan Jepun juga akan bertambah baik dan akan sentiasa berada di hadapan Malaysia. Dengan itu, Malaysia dan Jepun akan dapat melengkapi satu sama lain untuk satu tempoh masa yang panjang. ${ }^{34}$

Pada 14 Disember 1979, Pengerusi C. Itoh, Ryuzo Sejima menggesa kerajaan Malaysia untuk memberikan penekanan dalam meningkatkan kemudahan infrastruktur di Pantai Timur. Kerajaan juga diminta untuk tidak tergesa-tesa dalam permintaannya untuk pemindahan teknologi dari Jepun dan membenarkan lebih ramai kakitangan Jepun memasuki negara ini. Beliau juga mahukan dasar Bumiputera yang lebih fleksibel dan kelonggaran sekatan visa terhadap kakitangan yang dipinjamkan daripada syarikat induk di Jepun. ${ }^{35}$ Pada 26 Jun 1980, Dato' Seri Dr. Mahathir Mohamad menyatakan Malaysia akan menghantar lebih banyak misi pelaburan ke Jepun pada tahun hadapan bagi menarik para pelabur dan usahawan Jepun untuk melabur di negara ini. ${ }^{36}$

Pada 15 Januari 1981, dalam suatu majlis makan malam di bangunan Parlimen sempena menyambut lawatan rasmi Perdana Menteri Jepun, ${ }^{37}$ Tun Hussein Onn menyatakan kedatangan Zenko Suzuki sebaik dilantik menjadi Perdana Menteri Jepun ke Malaysia dan negara-negara lain di ASEAN menunjukkan kepentingan rantau ini kepada Jepun. Sememangnya kerajaan Malaysia berhasrat untuk terus mengukuhkan hubungan erat yang telah terjalin sekian lama antara kedua negara. Jepun juga telah banyak membantu dalam pembangunan ekonomi negara. Kredit Yen yang telah diberikan 
semenjak Rancangan Malaysia Pertama telah membantu kerajaan untuk memenuhi keperluan modal dalam sesetengah projek pembangunan utama. ${ }^{38}$ Bantuan teknikal Jepun dalam pelbagai bentuk juga tiada nilainya dalam membantu kerajaan Malaysia.

Tun Hussein Onn menzahirkan keyakinan bahawa Jepun akan terus membantu pembangunan negara. Malahan janji Zenko Suzuki bahawa Kredit Yen akan diberikan untuk Rancangan Malaysia Keempat sangat dihargai oleh kerajaan. Jepun sebagai sebuah negara maju yang bergantung kepada sumber bahan mentah daripada Malaysia, sudah tentu akan mendapat manfaat daripada pembangunan ekonomi negara. Tun Hussein Onn juga menyatakan Jepun merupakan rakan dagangan terbesar Malaysia pada tahun itu yang meliputi 21 peratus daripada jumlah eksport keseluruhan negara Jepun dan 23 peratus daripada jumlah import keseluruhan negara. ${ }^{39}$

Menjadi harapan Tun Hussein Onn agar kerjasama antara Jepun dan Malaysia boleh dieratkan lagi melalui bentuk kerjasama yang baru. Tun Hussein Onn juga menyatakan kerjasama antara Jepun dan Malaysia boleh dipereratkan lagi melalui bentuk kerjasama yang baru. Penyertaan syarikat-syarikat Jepun dalam pelbagai aktiviti pembuatan di Malaysia perlulah diperbanyakkan lagi untuk menyediakan barangan proses dan separa proses kepada syarikat induk di Jepun. Dengan cara ini, Malaysia boleh menggunakan dengan optimum bahan-bahan mentahnya, buruh dan tenaga yang ada, serta pada masa yang sama mendatangkan manfaat kepada industri Jepun. Tun Hussein Onn juga menyatakan kegembirannya kerana Jepun menunjukkan minat terhadap usaha pembangunan pertanian negara malah turut mengalualukan penyertaan Jepun dalam sektor ini. ${ }^{40}$ Sebagai sebuah negara pertanian, kerajaan Malaysia mengamalkan polisi untuk meningkatkan dan memperluas asas produktif sektor penting ini. Pembangunan Malaysia ini akan menawarkan pelbagai peluang untuk pelaburan, terutamanya dalam industri berasaskan pertanian.

Satu aspek yang sangat penting kepada semua usaha pembangunan Malaysia adalah akses kepada teknologi yang sesuai. Oleh itu, kerajaan Malaysia mengalu-alukan sebarang cadangan dari Jepun untuk pembangunan sumber manusia. Tun Hussein Onn juga menyatakan Malaysia sentiasa mengambil berat terhadap perkembangan politik di negara-negara lain. Beliau melahirkan harapan bahawa Jepun akan terlibat aktif dalam membantu memulikan situasi di Kemboja yang telah mengancam keamanan dan kestabilan di rantau ini. ${ }^{41}$ Kepentingan pelaburan asing terutama Jepun boleh dilihat dalam sasaran pelaburan yang ditetapkan di bawah Rancangan Malaysia Ketiga (1976-1980) untuk pencapaian oleh sektor pembuatan. 
Jika usahasama Malaysia dan Jepun dibangunkan dan tahap perdagangan antara kedua-dua negara bertambah, kerajaan perlu mempelajari dengan lebih lanjut mengenai struktur kewangan Jepun supaya institusi kewangan negara boleh memainkan peranan yang lebih besar dalam bidang ini. Kehadiran Jepun dalam bank-bank saudagar di Malaysia boleh memainkan peranan utama dalam membantu kerajaan mempelajari dengan lebih mendalam daripada institusi kewangan Jepun. Individu dari institusi kewangan negara juga boleh dihantar ke Jepun untuk mengkaji sistem Jepun. Dari segi sejarah, pembangunan Jepun selepas Perang Dunia Kedua bermula dengan hampir tiada rizab mata wang asing dan dengan program dasar perindustrian dan eksport mereka. Kini Jepun mempunyai salah satu rizab mata wang asing yang terkuat di dunia. Malaysia pula mempunyai rizab mata wang asing yang agak baik dan kadar eksportnya adalah dalam peratusan yang tinggi daripada keluaran negara kasar. Walau bagaimanapun, negara masih mempunyai masa yang panjang untuk memperbaiki kaedah mengukuhkan lagi rizab mata wang asing dan seterusnya meningkatkan nilai eksport. Dalam aspek ini kerajaan boleh mempelajari daripada pengalaman Jepun. ${ }^{42}$

Lawatan rasmi dan tidak rasmi dari Jepun sepanjang akhir tahun 1970-an dan awal 1980-an mengukuhkan lagi hubungan dua hala terutama dari segi perdagangan antara Malaysia dan Jepun. Misalnya lawatan delegasi Chubu Economic Federation of Japan diketuai Toshio Suzuki pada 15 Januari 1977,43 lawatan Presiden Dewan Perdagangan dan Perindustrian Jepun dan Pengerusi Persatuan Ekonomi Ekonomi Jepun-Malaysia, Shigeo Nagano pada 14 November $1977^{44}$ dan lawatan delegasi Jepun diketuai oleh Takeshi Izumi pada 15 Mei 1977.45

Pada awal 1980-an sebanyak 10 siri lawatan yang dilakukan oleh pihak Jepun ke Malaysia. Misalnya lawatan Menteri Perdagangan dan Perindustrian Antarabangsa Jepun, Toshio Kohmoto pada 4 Mei 1978, ${ }^{46}$ lawatan Menteri Jepun bagi Hal Ehwal Ekonomi Luar, Nubuhiko Ushiba pada 27 Julai 1978, ${ }^{47}$ lawatan dari rombongan kajian mengenai aktiviti pelaburan luar negara perusahaan Jepun di ASEAN yang diketuai oleh Taiichiro Matsuo pada 5 Oktober $1978,{ }^{48}$ lawatan 34 orang ahli Japan Chain Stores Association diketuai Presidennya, Noboru Gotoh pada 16 Januari 1979, ${ }^{49}$ lawatan daripada kajian pelaburan Jepun dari Tokyo Chamber of Commerce and Industry pada 29 Mac 1979, ${ }^{50}$ lawatan bekas Perdana Menteri Jepun, Takeo Fukuda pada 10 Julai 1979, ${ }^{51}$ lawatan Yang Dipertua JAMECA, S. Nagano pada 14 Disember $1979,{ }^{52}$ rombongan dari persekutuan ekonomi Kansai yang diketuai oleh M. Matsushita, pengerusi syarikat perusahaan elektrik Matsushita pada 24 Januari $1980,{ }^{53}$ lawatan seramai 10 orang yang diketuai oleh Menteri Perdagangan Antarabangsa dan Perindustrian Jepun, Rokusuke 
Tanaka pada 10 September $1980^{54}$ dan lawatan ahli-ahli perdagangan dari Kyushu-Yamaguchi Economic Federation pada 11 Februari 1981. ${ }^{55}$ Semua lawatan yang dilakukan ini adalah bertujuan untuk meningkatkan kerjasama ekonomi bagi pihak Jepun dan Malaysia.

Dalam pertemuan antara Rokosuke Tanaka dan Tun Hussein Onn di kediamannya, Tun Hussein Onn mengalu-alukan cadangan Rokosuke Tanaka untuk mewujudkan hubungan erat antara industri kecil dan sederhana kedua-dua buah negara. Beliau berpendapat kerjasama seumpama itu akan membantu Malaysia mendapatkan kepakaran dan pasaran bagi barang-barang diperbuat dan separuh diperbuat. Rokosuke Tanaka juga menyatakan kerajaannya akan mengkaji pengeluaran pinjaman baru bagi meliputi Rancangan Malaysia Keempat.

Selain itu, kerajaan Jepun juga menimbangkan rancangan empat serampang untuk kerjasama dengan Malaysia. Program empat serampang itu meliputi kuasa, memperkenalkan industri kecil dan sederhana, kemajuan perdagangan dalam barangan keluaran di samping perdagangan jenis lain dan kerjasama dalam pembangunan sumber manusia atau pembinaan negara. Rokosuke Tanaka juga menyatakan Jepun akan memberi sumbangan teknologi dan kewangan kepada Malaysia dalam usaha menyelesaikan masalah punca tenaga. Menurutnya, Jepun menyedari bahawa jika masalah punca tenaga yang menjadi kunci pembangunan ekonomi itu tidak diselesaikan, kemajuankemajuan lain tidak akan tercapai dengan mudah. Masalah punca tenaga itu telah dibincangkan ketika beliau menemui Menteri Perdagangan dan Perindustrian Malaysia, Dato' Seri Dr. Mahathir Mohamad. ${ }^{56}$

Hasil lawatan ekonomi yang berterusan ini membuahkan hasil melalui kemasukan pelaburan Jepun melalui usahasama dari semasa ke semasa. Antara pelabur-pelabur tersebut ialah Associated Steel Industries (M) Sdn. Bhd. pada tahun 1971, ${ }^{57}$ syarikat usahasama CEC $^{58}$ dan PERNAS-NEC Multiplexpada tahun 1973, ${ }^{59}$ Renesas Semiconductors (KL) Sdn. Bhd..$^{60}$ dan Penfibre Sdn. Bhd ${ }^{61}$ pada tahun 1974, Malaysia International Palm Oil Industries Sdn. Bhd. pada tahun 1975, ${ }^{62}$ Cheng Hua Engineering Works Sdn. Bhd. pada tahun 1976, UMW Auto Parts Sdn. Bhd. ${ }^{63}$ dan Hino Malaysia Sdn. Bhd. ${ }^{64}$ pada tahun 1977, Sanden Air Conditioning (M) Sdn. Bhd. pada tahun 1978, ${ }^{65}$ Yung Kong Galvanising Industries Berhad, Hong Leong Yamaha Motors Sdn. Bhd. dan Fujitec (M) Sdn. Bhd. pada tahun 1979, ${ }^{66}$ Fujitsu Component (M) Sdn. Bhd., ${ }^{67}$ Asian NDK Crystal Sdn. Bhd., ${ }^{68}$ Hitachi Consumer Product (M) Sdn. Bhd., ${ }^{69}$ Daihatsu (M) Sdn. Bhd. dan Buncho (M) Sdn. Bhd. pada tahun $1980 .{ }^{70}$

Berikutan misi promosi pelaburan ke Jepun antara bulan Oktober dan November 1978, beberapa syarikat dari Jepun telah 
memaklumkan kepada Perbadanan Kemajuan Ekonomi Negeri Johor akan kemungkinan menubuhkan kilang-kilang dan aktiviti-aktiviti lain di Johor. Pada 28 November 1978, Matsushita Precisions Industrial Company (M) Sdn. Bhd. telah memohon sebidang tanah seluas 16.5 ekar dalam Zon Perdagangan Bebas Senai bagi tujuan pembuatan komponen elektronik untuk eksport. Pada masa yang sama Ujiden Chemical Industry Company Ltd. pula bercadang untuk membina kilang di Kawasan Perindustrian Pasir Gudang bagi tujuan pemprosesan bauksit kepada jongkong yang akan dieksport ke Jepun. Kilang tersebut juga akan menghasilkan serbuk kasar dan pasir. Nippon View Hotel Co. Ltd. pula berminat untuk terlibat dalam usahasama dengan rakan kongsi Malaysia untuk menubuhkan sebuah hotel kelas pertama di Johor Bahru. ${ }^{71}$

Di samping itu, Nippon Sheet Glass Co. Ltd. pula berminat untuk membeli pasir silika yang dihasilkan oleh Perbadanan Kemajuan Ekonomi Negeri Johor. ${ }^{72}$ Nichiro Fisheries Co. Ltd. pula berminat untuk menubuhkan projek perikanan di Malaysia. ${ }^{73}$ Selain itu, terdapat juga cadangan usahasama antara Perak State Development Corporation dengan Toyo Rubber Industry Co. Ltd. bagi syarikat pengeluaran produk berasaskan getah dan cadangan usahasama antara Perak State Development Corporation dengan Rondex Rubber Thread Co. Ltd. bagi projek benang getah di Perak. ${ }^{74}$ Pada tahun 1979, Rokko-Misawa Company Ltd. telah menunjukkan minat terhadap projek rumah pasang siap di Johor Bahru. ${ }^{75}$

Hubungan sosial antara Jepun dan Malaysia juga terus dipereratkan dalam projek penghantaran pelajar-pelajar Malaysia ke Jepun dan peminjaman pakar dari Jepun ke Malaysia. Tujuannya adalah untuk memberi pendedahan melalui latihan teknikal dan vokasional kepada mereka. Antara tahun 1956 hingga 1980, seramai 852 orang pakar dari Jepun telah dihantar ke Malaysia manakala seramai 1,392 orang pelatih dari Malaysia telah mendapat latihan di Jepun. Pada masa yang sama, seramai 385 orang dari Japan Overseas Cooperation Volunteer telah dihantar untuk bekerja dengan rakyat Malaysia. Begitu juga terdapat kerjasama teknikal yang dibuat melalui rancangan Projek Pusat Teknologi Industri Logam, Projek Latihan Kejuruteraan Laut, Institusi Latihan Vokasional Mara dan sebagainya. ${ }^{76}$

Pada ketika ini, Jepun muncul sebagai rakan dagang utama Malaysia pada tahun 1980, dengan pegangan 20 peratus dari keseluruhan perdagangan luar Malaysia,77 serta mengatasi Singapura sebagai pelabur asing terbesar di Malaysia sejak tahun $1981 .{ }^{78}$ Menerusi temuramah individu yang dilakukan oleh Survey Research Group di bawah Hakuhodo iaitu syarikat pengiklanan Jepun mewakili Kementerian Luar Jepun merumuskan 93 peratus rakyat Malaysia 
menerima baik kemasukan syarikat-syarikat Jepun, 67 peratus rakyat Malaysia menganggap warga Jepun sebagai rajin dan 42 peratus rakyat Malaysia meletakkan Jepun sebagai destinasi pelancongan paling popular manakala Amerika Syarikat di tempat kedua dengan 36 peratus dan England di tempat ketiga dengan 35 peratus. $^{79}$

Pada 27 Mac 1981, Tun Hussein Onn menyatakan bahawa Rancangan Malaysia Keempat merupakan permulaan kepada pembangunan industri-industri berat dalam program pembangunan perusahaan Malaysia. Dalam usaha ini, Perbadanan Industri Berat Malaysia (HICOM) yang dimiliki sepenuhnya oleh kerajaan telah ditubuhkan pada tahun 1980 di bawah Dasar Perindustrian Berat. Bagi menjamin pembangunan perindustrian yang lebih pesat, kerajaan akan mengalakkan penubuhan lebih banyak perusahaan kecil dan sederhana bagi menampung perusahaan berat. ${ }^{80}$ Menariknya, Dasar Pandang Ke Timur yang dilancarkan pada tahun 1982 telah meletakkan Jepun sebagai rakan erat untuk menjayakan cita-cita perindustrian berat kerajaan yang telah bermula semasa pentadbiran Tun Hussein Onn.

Pada 25 April 1981, Tun Hussein Onn memuji Jepun yang telah memainkan peranan penting dalam pembangunan projek-projek perindustrian ASEAN. Ini merupakan perkembangan yang positif memandangkan program perindustrian ASEAN telah membuka ruang bagi penyertaan negara-negara maju. Kerjasama seperti ini akan memberi manfaat bersama kepada kedua-dua pihak. ${ }^{81}$ Selain menggalakkan kerjasama perindustrian serantau, penyertaan Jepun juga menandakan kemajuan Malaysia dalam usaha menerokai lapangan industri berat selaras dengan penekanan dan strategi perindustrian negara. ${ }^{82}$ Menjelang tahun 1981 kedudukan Jepun di Malaysia telah dikukuhkan lagi melalui perlaksanaan Dasar Pandang Ke Timur di bawah pimpinan Tun Dr. Mahathir Mohamad. ${ }^{83}$

\section{Kesimpulan}

Era pentadbiran Tun Hussein Onn telah merintis usaha ke arah dasar luar Malaysia yang bebas dan berkecuali melalui hubungan diplomatik dengan hampir semua negara tanpa mengira ideologi. Tun Hussein Onn meneruskan polisi pentadbiran Tun Abdul Razak yang telah menamatkan dasar pro-Barat dan anti Komunis Tunku Abdul Rahman yang keterlaluan. Sikap mementingkan kerjasama juga jelas kelihatan melalui usaha beliau mencari sahabat-sahabat baru baik di peringkat serantau mahupun antarabangsa melalui diplomasi Pan-Islam dan dasar berbaik dengan negara Afro-Asia di samping meneruskan hubungan tradisi dengan Barat. Beliau juga berusaha menjadikan Asia Tenggara 
sebagai Zone of Peace, Freedom and Neutrality (ZOPFAN) melalui Deklarasi Kuala Lumpur.

Penubuhan ZOPFAN telah menggalakkan Jepun untuk meningkatkan dan meluaskan dasar perdagangannya terhadap negara-negara ASEAN, khususnya Malaysia. Tun Hussein Onn menyifatkan Jepun berada dalam kedudukan yang baik untuk membantu Malaysia dalam pembangunan ekonomi. Ini kerana Jepun mempunyai pengalaman yang luas dalam bidang teknologi dan latihan. Jepun juga mempunyai golongan usahawan dan pengalaman untuk membantu pertumbuhan industri Malaysia, mempunyai pasaran yang boleh menyerap produk eksport dunia membangun dan mempunyai sumber-sumber yang boleh digunakan untuk memberi bantuan kepada Malaysia.

Kepentingan Jepun dalam ekonomi Malaysia dapat dilihat apabila bantuan kewangan Jepun membantu perlaksanaan Rancangan Malaysia Pertama, Kedua dan Ketiga. Jepun juga bersedia menghulurkan bantuan teknikal. Memandangkan kerajaan Malaysia tidak berminat dengan hubungan kebudayaan yang lebih erat antara kedua-dua negara, Tun Hussein Onn berharap agar pelaburan Jepun di Malaysia akan membantu pembangunan ekonomi dan sosial negara di samping akses yang lebih baik kepada pasaran Jepun. Disebabkan para pelabur Cina di Malaysia gagal memajukan industri pembuatan, kemasukan pelaburan dan teknologi Jepun dialu-alukan. Tun Hussein Onn juga berharap agar Jepun memainkan peranan dalam membentuk kerjasama antara sektor swasta Malaysia dan Jepun, serta sektor swasta Jepun dengan kerajaan Malaysia.

Penubuhan MAJECA dan JAMECA serta pelancaran Doktrin Fukuda telah menggalakkan lagi hubungan ekonomi antara Malaysia dan Jepun. Jika usahasama Malaysia dan Jepun dibangunkan dan tahap perdagangan antara kedua-dua negara bertambah, kerajaan Malaysia perlu mempelajari dengan lebih lanjut mengenai struktur kewangan Jepun supaya institusi kewangan negara boleh memainkan peranan yang lebih besar dalam bidang ini. Kerajaan Jepun pula menimbangkan rancangan empat serampang untuk kerjasama dengan Malaysia. Kunjungan pihak-pihak berkepentingan dari Jepun sepanjang akhir tahun 1970-an dan awal 1980-an mengukuhkan lagi hubungan dua hala antara Malaysia dan Jepun sehingga membawa kepada perlaksanaan Dasar Pandang Ke Timur pada tahun 1981. 


\section{Nota}

$1 \quad$ Ucapan Perdana Menteri Malaysia Ketika Membentangkan Usul Bagi Meluluskan Kajian Separuh Penggal Rancangan Malaysia Ketiga di Dewan Rakyat Pada 19 Mac 1979 dalam Koleksi Ucapan Perdana Menteri: Tun Hussein Onn, Pusat Sumber, Portal Rasmi Arkib Negara Malaysia.

2 Tiada nama, Joint venture invitation to Japanese dalam The Business Times, 17 Januari 1977, hlm. 10.

3 Tiada nama, Incentives Plan to Lure Foreign Investment dalam The Straits Times, 24 Februari 1977, hlm. 9.

$4 \quad$ Fail Jabatan Penerangan Malaysia No. G.15285, Kredit Yen, Upacara Menandatangani Pertukaran Nota-Nota Antara Kerajaan Malaysia dan Jepun, Bilik Gerakan Negara, Jabatan Perdana Menteri, Kuala Lumpur; 16.1.1978, 1978, foto.

5 Text of Interview Between The Prime Minister of Malaysia Yang Amat Berhormat Datuk Hussein Onn and NHK Broad Casting Station in Tokyo on September 20 dalam Foreign Affairs Malaysia 12 (1), 1979, hlm. 85.

6 Fail Jabatan Penerangan Malaysia No. G.15016, Tuan Takeo Fukuda Membuat Lawatan Rasmi Dua Hari ke Malaysia, Kuala Lumpur; 9.8.1977, 1977, foto.

7 J. Victor Morais, Hussein Onn: A Tryst With Destiny, Singapore: Times Books International, 1981, hlm. 211.

8 Lihat laporan bertajuk 'Press Release: Issued on the Occasion of the visit to Malaysia of H. E. Takeo Fukuda, Prime Minister of Japan, August 10, 1977, Embassy of Japan, Kuala Lumpur' dalam Public Record Office, Foreign Policy of Malaysia, 1977, hlm. 2.

$9 \quad$ Lihat laporan British High Commission Kuala Lumpur, 26 August 1977 bertajuk 'Mr Fukuda's Visit to Malaysia' dalam Public Record Office, Foreign Policy of Malaysia, 1977, hlm. 1.

10 Fail Jabatan Penerangan Malaysia No. G.15108, Jepun, Perdana Menteri, Datuk Hussein Onn, Lawatan Rasmi ke Tokyo, Kuala Lumpur; 18.9.1977, 1977, foto.

11 Lihat kertas bertajuk Shipping Services Between Malaysia and Japan, a Malaysian Viewpoint by Mr. Sulaiman Abdullah, Executive Deputy Chairman, Malaysian International Shipping Corporation Berhad dalam fail Lembaga Kemajuan Perindustrian Malaysia (MIDA) No. 8000/30 Jilid II, Malaysian Investment Mission to Japan 1978 - Malaysian Investment Promotion from 25 Oktober 1978 to 16 Januari 1979, tiada tahun, hlm. 2.

Aziz Zariza Ahmad, Mahathir: Warisan Perjuangan Langkah Ke Hadapan, Kuala Lumpur: Syarikat S. Abdul Majeed, 1991, hlm. 79.

$13 \quad$ Ibid., 77.

14 Tiada nama, Private sector gets Malaysian pledge dalam The Business Times, 15 November 1977, hlm. 12.

15 Tiada nama, PM's pledge to private sector dalam The Straits Times, 15 November 1977, hlm. 10.

16 Pejabat Perdana Menteri mendapat kerjasama dari Syarikat Perkapalan Antarabangsa Malaysia (MISC) untuk menubuhkan MAJECA. Penglibatan MISC dalam penubuhan MAJECA adalah disebabkan operasi syarikatnya 
bermula dengan pemberian dua buah kapal oleh kerajaan Jepun kepada kerajaan Malaysia sebagai pampasan perang pada lewat tahun 1960-an. Untuk maklumat lebih lanjut mengenai MAJECA dan JAMECA, sila lihat Khadijah Md. Khalid dan Lee Poh Ping, Whither the Look East Policy, Bangi: Penerbit Universiti Kebangsaan Malaysia, 2003, hlm. 66-73.

Untuk maklumat lebih lanjut tentang golongan pemimpin Malaysia dan pemimpin Jepun yang menyumbang kepada hubungan baik antara kedua pihak, sila lih. ibid., hlm. 54-65.

Salah satu daripada kajian terawal yang dilakukan ke atas kepentingan jaringan rasmi dan tidak rasmi Jepun terhadap negara negara Asia Tenggara telah dilakukan oleh Masashi Nishikara. Lihat Masashi Nishihara, Japanese and Sukarno's Indonesia: Tokyo Jakarta Relations, 19511966, Honolulu: The University Press of Hawaii, 1976. Kajian berikutnya cuba menjelaskan kelancaran Jepun dalam mengendalikan hubungan Jepun dengan negara-negara di rantau ini. Lihat Takashi Shiraishi, Japan and Southeast Asia dalam Peter J. Katzenstein dan Takashi Shiraishi (penyunting), Network Power: Japan and Asia, Ithaca, London: Cornell University Press, 1997, hlm. 169-194. Lihat juga W. Hatch dan Kozo Yamamura, Asia in Japan's Embrace: Building a Regional Production Alliance, New York: Cambridge University Press, 1996. Lihat juga Sueo Sudo, The Fukuda Doctrine and ASEAN: New Dimensions in Japanese Foreign Policy, Singapore: Institute of Southeast Asian Studies, 1992. Khadijah Md. Khalid dan Lee Poh Ping, Whither the Look East Policy, hlm. 81.

Peranan MAJECA-JAMECA telah menggambarkan kejayaan integrasi modal domestik dan asing yang juga membantu untuk mengurangkan ketegangan kaum antara kapitalis Melayu dan Cina. Dominasi berterusan kelas perniagaan Melayu bergantung kepada kemampuan mereka untuk menghasilkan pertumbuhan ekonomi yang tinggi, yang seterusnya bergantung kepada kemampuan Malaysia untuk mengintegrasikan kedua-dua modal kaum Cina dan pelaburan asing. Ini menjelaskan komposisi multi-etnik dalam MAJECA. Selain Unit Perancang Ekonomi (EPU) dan Syarikat Perkapalan Antarabangsa Malaysia (MISC), MAJECA juga dianggotai oleh wakil dari Dewan Perniagaan Melayu, Cina dan India, Persatuan Pengeluar Malaysia, Perbadanan Nasional Berhad (PERNAS), Petroliam Nasional Berhad (PETRONAS), Majlis Penanampenanam Kelapa Sawit Malaysia (MPOGC) dan Lembaga Kemajuan Tanah Persekutuan (FELDA). Bagi JAMECA pula, ahlinya adalah golongan peniaga Jepun yang mempunyai kaitan dengan Malaysia atau mempunyai rakan kongsi tempatan, dan juga semua firma besar Jepun termasuklah Mitsui, Matsushita, Mitsubishi, Sony dan lain-lain. Golongan peniaga Cina telah mendapat manfaat daripada keputusan kerajaan untuk menggalakkan lebih banyak usahasama ekonomi antara firma-firma Malaysia dan Jepun walaupun keputusan itu lebih memihak kepada orang Melayu di bawah DEB. Mereka terus melakukan kerjasama dengan kelas perniagaan Melayu baru bagi meningkatkan pengaruh mereka dalam kerajaan yang didominasi oleh parti UMNO sepanjang tempoh DEB. 
Fail Jabatan Penerangan Malaysia No. G.15996, Japan, Matsushita Electric Industrial Company Limited, Tuan Konosuke Matsushita Dikurniakan Darjah Utama Panglima Mangku Negara, Kuala Lumpur; 16.02.1979, 1979, foto. Md. Shukri Shuib, Pemilihan Fukuda Mampu Baiki Imej Jepun dalam Utusan Malaysia, 25 September 2007. Irene Tay Ying Chee, Tesis Sarjana Muda Sains Politik, Jabatan Sains Politik, Universiti Kebangsaan Malaysia, 1995, hlm. 48. Tiada nama, Kesan-kesan lawatan Fukuda ke Asia Tenggara kini diperhatikan dengan perasaan campur-aduk di Jepun dalam Berita Harian, 3 September 1977, hlm. 4.

26 Salah sebuah pengeluar terbesar plastik Jepun.

27 Tiada nama, KL investment climate is most attractive dalam The Business Times, 14 Ogos 1978, hlm. 2. Tiada nama, OPEN THE PANDORA BOX, JAPAN TOLD dalam The Business Times, 1 November 1978, hlm. 3. Tiada nama, Team up with foreign investors, says Mahathir dalam The Straits Times, 11 November 1978, hlm. 20. Tiada nama, JOINT VENTURES SOUGHT SOUGHT dalam The Business Times, 7 Oktober 1978, hlm. 12. Tiada nama, KL assures Japan on investment security dalam The Business Times, 4 Julai 1979, hlm. 3. Zainal Abidin Sulong, The Situation in Kampuchea dalam Foreign Affairs Malaysia 14 (4), 1980, hlm. 380. Fail Jabatan Penerangan Malaysia No. G.16287, Persidangan Menteri Ekonomi ASEAN Dirasmikan Oleh Encik Masayoshi Ohira; 26.11.1979, 1979, foto. Tiada nama, KL assures Tokyo dalam The Business Times, 18 Julai 1979, hlm. 3. Tiada nama, Call for better KL infrastructure dalam The Business Times, 15 Disember 1979, hlm. 5. Tiada nama, Wooing Japan dalam The Straits Times, 26 Jun 1980, hlm. 13. Fail Jabatan Penerangan Malaysia No. G.16757, Jepun, Zenko Suzuki, Perdana Menteri, Lawatan ke Malaysia, Sambutan Ketibaan Oleh Dato Hussein Onn, Perdana Menteri di Lapangan Terbang Subang, Kuala Lumpur; 15.1.1981, 1981, foto.

Speech by the Honourable Prime Minister at the Dinner Given in Honour of His Excellency Mr. Zenko Suzuki, The Prime Minister of Japan at Parliament House, Kuala Lumpur on 15th January, 1981 (Nombor klasifikasi fail arkib: TH 4:1:81) dlm. Arkib Negara Malaysia dengan kerjasama Jabatan Perdana Menteri, Ucapan-Ucapan Tun Hussein Onn 1981, hlm. 20.

$39 \quad$ Ibid., hlm. 20.

40 Ibid., hlm. 20-21.

$41 \quad$ Ibid., hlm. 21.

42 Lihat kertas bertajuk Japanese Malaysian Trade - Some Observations by a Malaysian Japanese Joint-Venture Financial Institution by Alex Lee, Executive Director of Development and Commercial Bank (Ltd.) Bhd. dan 
D and C Nomura Merchant Bankers Berhad dlm. fail Lembaga Kemajuan Perindustrian Malaysia (MIDA) No. 8000/30 Jilid II, Malaysian Investment Mission to Japan 1978 - Malaysian Investment Promotion from 25 October 1978 to 16 January 1979, tiada tahun, hlm. 2-4.

Tiada nama, Joint venture invitation to Japanese dalam The Business Times, 17 Januari 1977, hlm. 10.

Fail Jabatan Penerangan Malaysia No. G.15200, Istiadat Pengurniaan Persatuan Ekonomi Jepun-Malaysia, Tuan Shigeo Nagano Mengunjungi Datuk Hussein Onn di Pejabatnya, Kuala Lumpur; 14.11.1977, 1977, foto. Tiada nama, Japanese visit KL with $\$ 700 \mathrm{~m}$ plans dalam The Business Times, 17 Mei 1977, hlm. 1. Fail Jabatan Penerangan Malaysia No. G.15446, Lawatan Rasmi ke Malaysia, Menteri Perdagangan dan Perindustrian Antarabangsa, Jepun, Tuan Toshio Mengunjungi Datuk Hussein Onn di Pejabatnya, Jalan Dato' Onn, Kuala Lumpur; 4.5.1978, 1978, foto.

Fail Jabatan Penerangan Malaysia No. G.15601, Lawatan ke Malaysia, Ketibaan Menteri Negara Jepun, Encik Nubuhiko Ushiba Disambut Oleh Datuk Amar Haji Abdul Taib Mahmud, Lapangan Terbang Antarabangsa, Kuala Lumpur; 27.7.1978, 1978, foto.

Fail Jabatan Penerangan Malaysia No. G.15717, Rombongan Pelaburan Melawat dan Mengunjungi Menteri Perusahaan Utama, Encik Paul Leong Khee Seong, Kuala Lumpur; 05.10.1978, 1978, foto. Tiada nama, Malaysian fair for Japanese mission dalam The Business Times, 9 Januari 1979, hlm. 3. Tiada nama, Investment team in KL dalam The Business Times, 31 Mac 1979, hlm. 3.

51 Fail Jabatan Penerangan Malaysia No. G.16068, Jepun, Bekas Perdana Menteri, Encik Takeo Fukuda Mengunjungi Datuk Hussein Onn di Pejabatnya; 10.7.1979, 1979, foto.

52 Fail Jabatan Penerangan Malaysia No. G.16311, Japan-Malaysia Economic Association, Yang Dipertua, Encik S. Nagano. Kunjungan Menemui Datuk Hussein Onn, Kuala Lumpur; 14.12.1979, 1979, foto.

53 Fail Jabatan Penerangan Malaysia No. G.16355, Jepun, Rombongan Persekutuan Ekonomi Kansai. Kunjungan Hormat ke atas Perdana Menteri, Datuk Hussein Onn, Kuala Lumpur; 24.1.1980, 1980, foto.

54 Fail Jabatan Penerangan Malaysia No. G.16600, Lawatan ke Malaysia, Menteri Perdagangan Antarabangsa dan Perindustrian Jepun, Encik Rokosuke Tanaka Mengunjungi Tengku Ahmad Rithauddeen di Pejabatnya, Kuala Lumpur; 10.9.1980, 1980, foto.

Fail Jabatan Penerangan Malaysia No.16780, Jepun, Kyushu-Yamaguchi Economic Federation, Lawatan ke Asia Tenggara, Kunjungan Muhibbah ke atas Encik Kassim Ahmad, Setiausaha Parlimen, Kementerian Luar Negeri, Kuala Lumpur; 11.2.1981, 1981, foto.

56 Tiada nama, Hussein Onn alu-alukan kerjasama industri Malaysia - Jepun dalam Utusan Malaysia, 11 September 1980.

57 Data diperoleh daripada Selangor State Investment Centre (SSIC). 
Fail Lembaga Kemajuan Perindustrian Malaysia (MIDA) No. 8000/30 Jilid II, Malaysian Investment Mission to Japan 1978 - Malaysian Investment Promotion from 25 October 1978 to 16 January 1979, tiada tahun.

Kumpulan PERNAS, Multiplex factory in another tie-up with Japan dalam Suara PERNAS 1 (2), 1973.

60 Data diperoleh daripada Selangor State Investment Centre (SSIC).

61 Ucapan Perdana Menteri di Upacara Merasmikan Pembukaan Kilang Syarikat Penfibre Sendirian Berhad di Kawasan Perindustrian Prai, Pulau Pinang Pada 27hb Disember, 1974 (Nombor klasifikasi fail arkib: TR 8:12:74) dalam Arkib Negara Malaysia dengan kerjasama Jabatan Perdana Menteri, Ucapan-Ucapan Tun Haji Abdul Razak bin Hussein 1974, Kuala Lumpur, Ibrahim bin Johari, P.I.S, Ketua Pengarah Percetakan Semenanjung Malaysia, 1979, hlm. 527-531. Kumpulan PERNAS, PERNAS Engineering in Venture Project with Japanese Investors dalam Suara Pernas 3 (4), 1976. Data diperoleh daripada Selangor State Investment Centre (SSIC). Shawkath Azde, Keselamatan dan Keselesaan Ditingkatkan dalam Kosmo, 14 Disember 2012. Data diperoleh daripada Selangor State Investment Centre (SSIC). Ibid.

Tiada nama, Shah Alam plant to make wafers dalam The Star, 25 Mac 1989, hlm. 4. Lihat juga Gouri Paranisamy, Tesis Sarjana Muda, Jabatan Sejarah, Universiti Kebangsaan Malaysia, 1998/1999, hlm. 53. Fail Jabatan Penerangan Malaysia No. G.16399, Kilang Syarikat Asian NDK Crystal Sdn. Bhd. Pembukaan, Datuk Seri Dr. Mahathir Mohamad Mendengar Penerangan Oleh Pengerusi Syarikat, Kuala Lumpur; 15.3.1980, 1980, foto. Data diperoleh daripada Selangor State Investment Centre (SSIC). Ibid.

Lihat kertas bertajuk Investment Promotion Mission to Japan October/ November 1978 dalam fail Lembaga Kemajuan Perindustrian Malaysia (MIDA) No. 8000/30-1 Follow Up, Malaysian Investment Mission to Japan 1978 - Malaysian Investment Promotion from 28 November 1978 to 4 January 1979, tanpa tahun, hlm. 1-3.

Ibid.

Lihat surat bertajuk Maklumat-maklumat berkenaan Perusahaan Perikanan di Malaysia dalam fail Lembaga Kemajuan Perindustrian Malaysia (MIDA) No. 8000/30-1 Follow Up, Malaysian Investment Mission to Japan 1978 - Malaysian Investment Promotion from 28 November 1978 to 4 January 1979, tiada tahun.

Lihat surat bertajuk Rubber Based Products - A Proposal for Joint Venture bertarikh 29 Disember 1978 dan surat bertajuk Proposal for Latex Thread Project in Perak, Malaysia bertarikh 5 Disember 1978 dalam fail Lembaga Kemajuan Perindustrian Malaysia (MIDA) No. 8000/30 Jilid II, Malaysian Investment Mission to Japan 1978 - Malaysian Investment Promotion from 25 October 1978 to 16 January 1979, tiada tahun.

75 Lihat surat bertajuk Investment Promotion Mission to Japan October/ November, 1978 bertarikh 23 Januari 1979 dalam fail Lembaga Kemajuan 
Perindustrian Malaysia (MIDA) No. 8000/30-1 Follow Up, Malaysian Investment Mission to Japan 1978 - Malaysian Investment Promotion from 28 November 1978 to 4 January 1979, t.th.

76 Ooi Loy Mui, Tesis Sarjana Muda Sastera, Jabatan Sejarah, Universiti Kebangsaan Malaysia, 1997/1998, hlm. 51.

77 J. Tann Kok Aun, I Go East: Learning From the Japanese Experience, Kuala Lumpur, Milimex Corpn. Publishers, 1982, hlm. 12.

78 Tiada nama, Japanese investment dalam The Business Times, 21 Mac 1983, hlm. 1.

79 Tiada nama, Japanese project a good image dalam The Business Times, 21 Januari 1980, hlm. 12.

80 Usul dan Ucapan Yang Amat Berhormat Perdana Menteri Semasa Membentangkan Rancangan Malaysia Keempat di Dewan Rakyat, Kuala Lumpur Pada 27hb Mac, 1981 (Nombor klasifikasi fail arkib: TH 1:3:81) dalam Arkib Negara Malaysia dengan kerjasama Jabatan Perdana Menteri, Ucapan-Ucapan Tun Hussein Onn 1981, hlm. 29. Speech by the Honourable The Prime Minister at the Launching of the ASEAN Bintulu Fertilizer Sdn. Bhd. at the Kuala Lumpur Regent on 25th April, 1981 (Nombor klasifikasi fail arkib: TH3:4:81) dalam ibid., hlm. 45. Ibid., hlm. 43.

83 Nobuo Kawabe, Masalah dan Perspektif Pengurusan Jepun di Malaysia dalam Shoichi Yamashita (penyunting), Pemindahan Teknologi Dan Pengurusan Jepun Ke Negara-Negara ASEAN, Terjemahan Nazlifa Md. Ali. Kuala Lumpur: Dewan Bahasa Dan Pustaka, 1993, hlm. 276. 